\title{
JEZZYKOZNAWSTWO
}

\author{
Michat Sajewicz \\ DOI: $10.15290 /$ bb.2019.11.18 \\ UMCS w Lublinie \\ https://orcid.org/0000-0001-8468-3010

\section{Pejoratywne nazwy subiektów oznaczające człowieka ze względu na ruch, przemieszczanie się w przestrzeni w peryferyjnych gwarach białoruskich okolic Lewkowa Starego na Białostocczyźnie}

\section{Uwagi wstępne}

Celem artykułu jest opis dewerbalnych pejoratywnych nazw subiektów określających człowieka ze względu czynności związane z ruchem, przemieszczaniem się w przestrzeni. W artykule skoncentrowałem się głównie na ukazaniu środków słowotwórczych służących do tworzenia badanych derywatów oraz synonimiki struktur słowotwórczych.

$\mathrm{W}$ artykule zastosowano metodę synchronicznej analizy materiału słowotwórczego. Analizie słowotwórczej poddano wyłącznie formacje o strukturze przejrzystej, współcześnie motywowane. Podstawę teoretyczną opracowania stanowi dorobek polskiej i rosyjskiej szkoły słowotwórczej, której przedstawiciele nawiązują do teorii słowotwórczej Grigorija O. Winokura ${ }^{1}$ i Miloša Dokulila².

Bazę materiałową opracowania stanowi około 170 pejoratywnych dewerbalnych nazw subiektów poświadczonych w gwarach białoruskich okolic Lewkowa Starego. Materiał pochodzi z 8 wsi położonych na terenie gminy Narewka w województwie podlaskim. Są to miejscowości: Lewkowo Stare,

\footnotetext{
1 Г. Винокур, Заметки по русскому словообразованию, [в:] Избраннье работы по русскому языку, Изд. Учпедгиз, Москва 1959, с. 419-442.

2 M. Dokulil, Tvořeni slov v češtině, 1. Teorie odvozování slov, Nakladatelství Československé akademie věd, Praha 1962.
} 
Lewkowo Nowe, Bernacki Most, Ochrymy, Kapitańszczyzna, Podlewkowie, Eliaszuki i Michnówka.

Okolice Lewkowa Starego zamieszkują obecnie w głównej mierze potomkowie białoruskojęzycznych chłopów pochodzących spod Wołkowyska i Świsłoczy, których na początku XVII wieku sprowadzili do swoich dóbr, zwanych Narewką-Lewkowem, ich właściciele Massalscy ${ }^{3}$. Nad Narewką ludność białoruskojęzyczna zetknęła się z przybyłą z Podlasia ludnością ukraińskojęzyczną ${ }^{4}$.

Mieszkańcy okolic Lewkowa Starego posługują się na co dzień gwarą białoruską ${ }^{5}$. Do cech charakterystycznych tej gwary należą m.in. akanie, dziekanie i ciekanie oraz miękka wymowa spółgłosek przedniojęzykowo-zębowych przed $* e \mathrm{i} * i$. Przedostały się do niej również pewne elementy charakterystyczne dla gwar ukraińskich, por. np. występowanie $o$ w niektórych sylabach poakcentowych, stwardnienie spółgłosek wargowych przed * $e$. Gwary okolic Lewkowa Starego są jednak w swojej podstawie gwarami białoruskimi i należą do południowo-zachodniego dialektu tych gwar 6 .

\section{Cechy słowotwórstwa gwarowego}

Cechą odróżniającą słowotwórstwo gwarowe od słowotwórstwa języków literackich jest zdecydowana przewaga w gwarach derywatów ekspresywnych, w szczególności o nacechowaniu pejoratywnym. Anna Kowalska zauważa, że

dialekty charakteryzują się znacznie większą spontanicznością procesów, a także większą różnorodnością środków językowych służących powstawaniu nazw ekspresywnych niż język literacki ${ }^{7}$.

3 D. Michaluk, Dobra i miasteczko Narewka na tle dziejów regionu (do końca XIX w.), Urząd Gminy w Narewce, Białystok - Narewka 1997, s. 33.

4 Atlas gwar wschodniostowiańskich Białostocczyzny, t. 1, red. Glinka, A. Obrębska-Jabłońska, J. Siatkowski, Zakład Narodowy im. Ossolińskich, Wydawnictwo PAN, Wrocław - Warszawa - Kraków - Gdańsk 1980, s. 23; J. Wiśniewski, Zarys dziejów osadnictwa na Białostocczyźnie, [w:] Atlas gwar wschodniostowiańskich Białostocczyzny, t. 1..., s. 14-27.

5 Atlas gwar wschodniosłowiańskich Białostocczyzny, t. 1 ..., s. 122; Kulturowo-językowe dziedzictwo Podlasia, t. 1. Opis socjolingwistyczny regionu na tle uwarunkowań historycznych, red. N. Barszczewska, M. Chaustowicz, M. Timoszuk, Katedra Białorutenistyki Uniwersytetu Warszawskiego, Warszawa 2016, s. 58.

6 Kulturowo-jezykowe dziedzictwo Podlasia, t. 1..., s. 56-64; M. Sajewicz, O białorusko-ukraińskiej granicy językowej na Białostocczyźnie, „Rozprawy Slawistyczne” 1997, nr 12, s. $91-107$. 
W gwarach szczególnie często są notowane

nacechowane emocjonalnie, przeważnie negatywnie, nazwy dotyczące człowieka, bowiem ekspresja uczuć, ocen należy do tej sfery zachowań językowych, które ujawniają się w spontanicznych bezpośrednich kontaktach międzyludzkich ${ }^{8}$.

Tadeusz Malec zaznacza, że zjawisko to wiąże się

z mniejszą dyscypliną intelektualną mieszkańców wsi, z mniejszym celowym wykorzystywaniem środków językowych. Procesy językowe na terenie gwary przebiegają w sposób mniej kontrolowany świadomie, a bardziej naturalnie ${ }^{9}$.

Występujące powszechnie $\mathrm{w}$ gwarach derywaty pejoratywne nazywają osoby wykazujące skłonność do czynności nieakceptowanych w społecznościach wiejskich, wywołujących w mówiącym określone uczucia negatywne.

Pejoratywy osobowe wskazują, jak stwierdza Renata Marciniak-Firadza,

na takie zachowania, które odbiegają od normy, kłócą się z poczuciem moralnym, wpływają w jakiś sposób na naruszenie zasad życia społecznego ${ }^{10}$.

Pejoratywy osobowe piętnujac osoby, które pod pewnymi względami różnią się od pozostałych członków określonej wspólnoty językowo-kulturowej ${ }^{11}$.

W potocznym myśleniu inny członek społeczności wiejskiej jest dla mówiącego potencjalnym konkurentem, przeciwnikiem, którego należy zdyskredytować, poniżyć za jego przywary i ułomności. Mówiący dostrzega i potępia w innym człowieku to, co uważa za złe, niestosowne i odmienne od norm przyjętych $\mathrm{w}$ danej społeczności ${ }^{12}$.

7 A. Kowalska, Z badań nad mazowiecka leksyka ekspresywna (nazwy 'człowieka z wytrzeszczonymi oczami'), „Zeszyty Naukowe Uniwersytetu Gdańskiego. Prace Językoznawcze", 1993, nr 17-18, s. 129-133.

8 R. Marciniak-Firadza, Nazwy osobowych wykonawców czynności w gwarach małopolsko-mazowieckiego pogranicza językowego, cz. I. Studium słowotwórczo-leksykalne, Wydawnictwa Uniwersytetu Łódzkiego, Łódź 2013, s. 212.

9 T. Malec, Budowa rzeczowników i przymiotników w gwarze wsi Rachanie pod Tomaszowem Lubelskim, Zakład Narodowy im. Ossolińskich, Wrocław 1976, s. 94.

10 R. Marciniak-Firadza, op. cit., s. 212-213.

11 T. Kurdyła, Funkcje formantów rzeczownikowych w polszczyźnie ludowej (na przykładzie trzech wsi podkarpackich), Uniwersytet Jagielloński, Wydział Polonistyki, Kraków 2011, s. 173; J. Matusiak-Kempa, Dobre i zle w ludzkiej mowie - o wartościowaniu utrwalonym $w$ dawnych przezwiskach, „Poznańskie Studia Polonistyczne. Seria Językoznawcza" 2017, vol. 24 (44), nr 1, s. 88-89.

12 A. Rejter, Leksyka ekspresywna w historii jezzyka polskiego. Kulturowo-komunikacyjne konteksty potoczności, Wydawnictwo Uniwersytetu Śląskiego, Katowice 2006, s. 155. 
Antropocentryzm potocznego postrzegania rzeczywistości sprawia, że członkowie społeczności wiejskich znacznie częściej okazują dezaprobatę wobec otaczającej ich rzeczywistości niż manifestują wobec niej postawę aprobaty ${ }^{13}$.

\section{Zdaniem Tomasza Kurdyły}

w tworzeniu nazw osobowych, stanowiących dużą część systemu słowotwórczego polszczyzny mówionej wsi, potrzeba ekspresji wyprzedza w gwarach potrzebę samej nominacji, dominującej w języku ogólnopolskim ${ }^{14}$.

Słowotwórstwo gwarowe charakteryzuje się także występowaniem licznych synonimicznych konstrukcji słowotwórczych. Rozbudowane szeregi synonimiczne są notowane $\mathrm{w}$ szczególności w gwarach peryferyjnych, w tym także na pograniczu polsko-białorusko-ukraińskim na Białostocczyźnie ${ }^{15}$.

Pawieł Sciacko zaznacza, że zjawisko synonimiczności struktur słowotwórczych zostało wywołane

багатымі словаўтваральнымі магчымасцямі народна-дыялектнай мовы, выкліканымі разгалінаванай сыстэмай народных гаворак, узаемадзеяннем розных дыялектаў і іх дэрывацыйнымі асаблівасцямі, уздзеяннем на гаворкі літаратурных моў, а таксама гаворак суседніх народай, захаваннем у народнай мове словаўтваральных тыпаў і мадэлей мінулых эпох і фармаваннем новых дэрывацыйных сродкаў, імкненнем носьбітаў мовы да вобразнасці, эмацыянальнасці выказвання, а таксама ўзаемадзеяннем паміж сабой розных словаўтваральных асной і тыпаў ${ }^{16}$.

\section{Charakterystyka ogólna dewerbalnych pejoratywnych nazw subiektów w badanych gwarach peryferyjnych}

System słowotwórczy peryferyjnych gwar białoruskich okolic Lewkowa Starego na Białostocczyźnie charakteryzuje się nadzwyczaj bogatym inwentarzem środków wykorzystywanych do uzewnętrzniania uczuć i do obrazo-

13 A. Grzesiuk, Składnia wypowiedzi emocjonalnych, Uniwersytet Marii Curie-Skłodowskiej, Lublin 1995, s. 184.

14 T. Kurdyła, op. cit., s. 173.

15 M. Sajewicz, Dublety strukturalne w kategorii dewerbalnych nomina agentis $w$ gwarach z pogranicza białorusko-ukrainskiego na Białostocczyźnie, „Rozprawy Slawistyczne” 1989, 4, s. 265-271; M. Sajewicz, Derywacja sufiksalna osobowych nazw subiektów w nadnarwiańskich gwarach białoruskich Białostocczyzny. Deverbativa, deadiectiva, Uniwersytet Marii Curie-Skłodowskiej w Lublinie, Lublin 2002, s. 462-465.

16 П. Сцяцко, Беларускае народнае словаўтварэнне. Афіксальныя назойнікі, Навука і тэхніка, Мінск 1977, с. 291. 
wania osobowości nadawcy ${ }^{17}$. S. Grabias zauważa, że osobowość nadawcy najpełniej ujawnia się w emocjach, dlatego też badanie przejawów emocji, zdaniem tego badacza, pozostaje zasadniczym zagadnieniem teorii ekspresji $^{18}$. Zadaniem językoznawców jest zatem udzielenie odpowiedzi na pytanie, co czuje nadawca i jak swoje uczucia uzewnętrznia ${ }^{19}$.

Dewerbalne pejoratywne nazwy subiektów są tworzone w gwarach białoruskich okolic Lewkowa Starego za pomocą 84 formantów słowotwórczych. Nacechowanie ujemne derywatów nie zawsze jednak wynika z udziału określonego formantu słowotwórczego w procesie derywacji. Często wiąże się ona

z takimi aspektami tego procesu, jak przeniesienie wartości emocjonalnej z wyrazu podstawowego na pochodny, nowość czy aluzja ${ }^{20}$.

Odczasownikowe pejoratywne nomina subiecti są rezultatem kojarzenia pejoratywnych, melioratywnych i neutralnych FS z PS czasowników neutralnych bądź nacechowanych ujemnie. W niniejszym opracowaniu uwzględniono cztery grupy pejoratywów osobowych powstałych w wyniku połączenia wymienionych typów FS z PS czasowników neutralnych i nacechowanych ujemnie ${ }^{21}$ :

- pejoratywy powstałe w wyniku połączenia neutralnych FS z PS czasowników nacechowanych ujemnie, por. np. bt'udn'ik $\leq$ bluz'ic' 'błądzić, mylić drogę', trap'al'ščy $\leq$ trap'ac' 'iść, wlec się';

- pejoratywy powstałe w wyniku połaczenia pejoratywnych FS z PS czasowników neutralnych, por. np. prai d'aka $\leq$ prains'c'i, por. praes. praind-'ut 'przejść', uc'ik'ainto $\leq$ uc'ik'ac' 'uciekać';

- pejoratywy powstałe w wyniku połączenia pejoratywnych FS z PS czasowników nacechowanych ujemnie, por. np. d'yndaunka $\leq d^{\prime} y n d a c$ ' 'chodzić niezgrabnie', št'ynda $\leq \check{s l}$ '”ac:e 'włóczyć się'.

- pejoratywy powstałe w wyniku połączenia melioratywnych FS z PS cza-

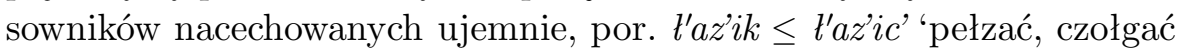
się', v'erc'ik $\leq$ varc'éc:e 'wiercić się'.

Derywaty mogą zawierać w sobie nie do końca określone negatywne wartości ${ }^{22}$. Charakter wyrażonej przez nadawcę emocji ujemnej można sprecy-

17 M. Sajewicz, Derywacja sufiksalna osobowych nazw subiektów..., s. 414-435.

18 S. Grabias, O ekspresywności języka. Ekspresja a słowotwórstwo, Wydawnictwo Uniwersytetu Marii Curie-Skłodowskiej, Lublin 1980, s. 18.

19 Ibidem.

20 Ibidem, s. 37-38.

21 Ibidem, s. 175.

22 K. Gołdowski, Ekspresywizmy osobowe jako relewantne sktadniki kompetencji językowo-kulturowej mieszkańców gminy Iwanowice w pow. krakowskim, Kraków 2015, s. 24. Pobrano z: http://www.academia.edu/19519069 (dostęp: 30.05.2017). 
zować na podstawie kontekstu, w jakim dany derywat został użyty ${ }^{23}$. W tym celu uwzględniono w trakcie badań konteksty ilustrujące użycie poszczególnych derywatów, których jednak w artykule z przyczyn technicznych nie przytoczono.

Wartość ekspresywna, którą wnoszą do derywatu FS, może być w derywacie odpowiednio aktualizowana (neutralizacja, intensyfikacja, całkowita zmiana nacechowania) ${ }^{24}$.

Renata Marciniak-Firadza trafnie zauważa, że derywaty są znakomitym środkiem sygnalizowania negatywnej oceny,

a do degradacji przedmiotu wypowiedzi można wyzyskać dodatkowe cechy znaczeniowe ukryte $\mathrm{w}$ ich strukturze: bądź w podstawie słowotwórczej, bądź w charakterystycznym formancie ${ }^{25}$.

Zaistniała wobec tego konieczność uwzględnienia zarówno specyfiki poddanych analizie odczasownikowych pejoratywów osobowych, jak również znaczenia leksykalnego wyrazów motywujących. W trakcie przeprowadzonych badań dokładnej analizie poddano konteksty, w jakich derywaty pejoratywne zostały użyte, ponieważ mogą one zawierać w sobie niedookreślone negatywne wartości.

Ustalenie grup znaczeniowych badanych pejoratywów jest utrudnione ze względu na krzyżowanie się pól semantycznych komponentów znaczenia oraz rozbudowaną synonimikę tego typu nazw. Badania wykazały, że do najbardziej reprezentatywnych grup znaczeniowych należą:

- chodzić bezustannie;

- chodzić z trudem;

- chodzić niezgrabnie;

- chodzić drobnym krokiem;

- chodzić chwiejnym krokiem, zataczać się;

- chodzić spiesząc się;

- chodzić powoli;

- chodzić kulejąc;

- chodzić bez celu;

- iść, pozostawiając na powierzchni brudne ślady;

- iść, powodując powstawanie określonych odgłosów;

\footnotetext{
23 A. Rejter, op. cit., s. 75-76.

24 S. Grabias, op. cit., s. 58.

25 R. Marciniak-Firadza, Dukawka, gulgot, sepiot..., czyli jak w gwarach matopolsko-mazowieckiego pogranicza językowego nazywa się człowieka, który się jąka, betkocze czy sepleni, „Rozprawy Komisji Językowej ŁTN”, 2017, LXIV, s. 198; zob. także: Grabias, op. cit., s. 171.
} 
- iść, powłócząc nogami;

- iść, człapiąc nogami;

- pospiesznie sie oddalać, uciekać;

- kręcić się pod nogami;

- pełzać, czołgać się;

- ślizgać się po śliskiej powierzchni;

- wspinać się, wdrapywać się gdzieś.

Określane osoby mogą wywoływać w mówiącym takie typy emocji negatywnej, jak: agresja, dystans, gniew, grubiaństwo, ironia, lekceważenie, lęk, negacja, niechęć, niedowierzanie, nienawiść, niezadowolenie, nostalgia, obraza, oburzenie, pogarda, politowanie, rozczarowanie, rubaszność, smutek, strach, tęsknota, wrogość, wstręt, wulgarność, zakłopotanie, zazdrość, zdenerwowanie, złośliwość, zniecierpliwienie, żal ${ }^{26}$.

\section{Typy słowotwórcze badanych pejoratywnych nazw subiektów}

- $\mathrm{N}_{\mathrm{SUB}}$ z FS - to (41):

b'éyało $\leq$ b'éyac' 'ciągle biegać, spieszyć się', br'ontało $(1) \leq$ br'ontac:e 'chodzić bez celu', brontało $(2) \leq$ br'ontac:e 'plątać się pod nogami', c'oyało $\leq$ c'oyac:e 'włóczyć się, często się przemieszczać', čar'apkało $\leq$ čar'apkac:e

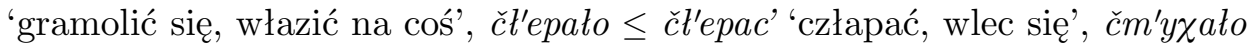
$\leq \check{c} m^{\prime} y \chi a c$ ' 'uciekać, czmychać', dr'yndato $\leq d r^{\prime} y n d a c$ ' 'bezustannie chodzić, być w ciągłym ruchu', dr'ypało $\leq d r^{\prime} y p a c$ ' 'bezustannie chodzić, być w ciągłym ruchu', d'yndało $\leq$ d'yndac' 'chodzić ociężale, powłócząc nogami', d'yrdało $\leq d^{\prime} y r d a c$ ' 'iść pośpiesznie, pędzić', $3^{\prime} y$ yało $\leq 3^{\prime} y$ y ac' 'iść podskakując', f'ikało $\leq$ f'ikac' 'turlać się, robić fikołki', $\chi l^{\prime \prime} u p a ł o \leq \chi l^{\prime \prime} u p a c$ ' 'iść

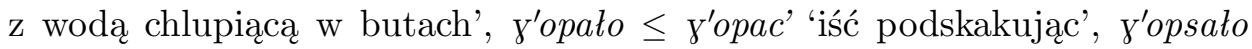
$\leq \gamma^{\prime}$ opsac' 'iść podskakując', in'érzało $(2) \leq i^{\prime}$ èrzac:e 'wiercić się', kar'apkało $\leq k a r^{\prime} a p k a c: e$ 'gramolić się, włazić', kt'yndało $\leq k t^{\prime} y n d a c$ ' 'niezgrabnie chodzić, powłócząc nogami', kt'ypało $\leq k t^{\prime} y p a c$ ' 'iść ociężale, wlec się', k'ouzało $\leq k^{\prime} o u z a c: e$ 'ślizgać się, np. po oblodzonym chodniku', kušt'ykało $\leq k u s ̌ t ' y k a c$ ' 'iść utykając', l'etało $\leq$ l'etac' 'biegać, być ciągle w ruchu', pl'ontało (3) $\leq$ pl'ontac:e 'plątać się, łazić', p'ouzało $(1) \leq$ p'ouzac' 'raczkować (o dziecku)', p'ouzało (2) $\leq$ p'ouzac' 'łazić na czworakach (o pijaku)', p'utało (2) $\leq$ p'utac:e 'plątać się, łazić', r'eindało $\leq$ r'eindac:e 'chodzić kiwając się na

26 W. Lubaś, Polskie gadanie. Podstawowe cechy i funkcje potocznej odmiany polszczyzny, Wydawnictwo Uniwersytetu Opolskiego, Opole 2003, s. 186-203. 


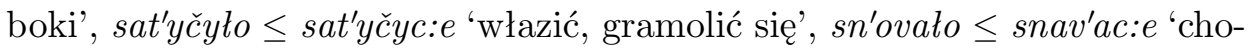
dzić bez celu, snuć się', s'l'izgato $\leq$ s'l'izgac:e 'ślizgać się np. na oblodzonym

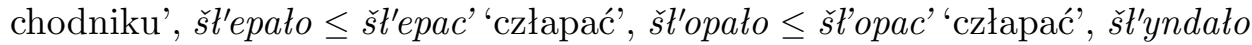
$\leq \check{s} t^{\prime} y n d a c$ ' 'lazić, włóczyć się', š'oryato $\leq$ šoryac' 'iść szurając butami',

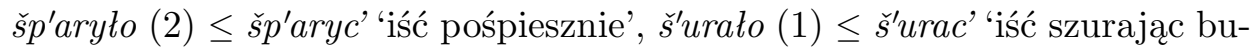
tami', šv'endało $\leq \check{s} v^{\prime} e n d a c: e$ 'włóczyć się', tarab'an'iło $\leq$ tarab'an'ic:e 'gramolić się, włazić', tr'épało $\leq t^{\prime} \dot{e}^{\prime}$ 'ac 'iść z trudem', t'upało $\leq t^{\prime} u p a c$ ' 'iść, głośno tupiąc butami', uc'ik'ainło $\leq$ uc'ik'ac' 'uciekać', vałač'yło $\leq$ vałačyc:e 'chodzić bez celu, włóczyć się'.

- $\mathbf{N}_{\text {SUB }}$ z FS -un (33):

b'iy'un $\leq$ b'èzac' 'biegać bezustannie', bryk'un $\leq$ br'ykac' 'żywiołowo biegać podskakując, swawolić', čłap'un $\leq$ čt'epac' 'człapać, wlec się', čmyx'un $\leq \check{c} m^{\prime} y \chi a c$ ' 'uciekać, czmychać', čyk'etd'un $\leq \check{c} y k$ 'etd'ac' 'iść utykając, kulejąc', dapt'un $\leq$ dapt'ac:e 'kręcić się pod nogami', drat'un $\leq$ dratav'ac' 'iść, jechać pospiesznie', drypt'un $\leq$ drypt'ac' 'dreptać', $\chi$ 'it'un $\leq \chi^{\prime} i t^{\prime} a c: e$ 'zataczać się', dryp'un $\leq d r^{\prime} y p a c$ ' 'iść ociężale, $\mathrm{z}$ trudem', $\chi a d^{\prime} u n \leq \chi a 3^{\prime \prime} i c$ ' 'łazić, wałęsać się', in iizd'un $\leq$ i'ėz'z'ic' 'jeździć (cały czas)', kal'ad'un $\leq$ kal'adav'ac' 'włóczyć się po wsi, chodzić od domu do domu', kauz'un $\leq k^{\prime}$ 'ouzac:e 'ślizgać się', kavyrk'un $\leq$ kavyrk'ac:e 'posuwać się do przodu robiąc fikołki', klynd'un $\leq k t^{\prime} y n d a c$ ' 'niezgrabnie chodzić', kul' $\gamma^{\prime} u n \leq k u l^{\prime} y^{\prime} a c$ ' 'kuleć, utykać na nogę', l'it'un $\leq$ l'etac' 'latać, biegać', mašer'un $\leq$ mašerav'ac' 'iść za-

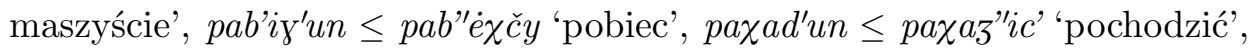
pauz'un $\leq$ p'ouzac'//pausc"i 'chodzić na czworakach', račk'un $\leq$ račkav'ac' 'raczkować', reidd'un $\leq$ r'eindac:e 'kiwać się na boki', spacer'un $\leq$ spacerav'ac' 'spacerować, chodzić bez celu', s'l'izg'un $\leq$ s'l'izgac:e 'ślizgać sie, np. po oblodzonym chodniku, šar'un $\leq$ šarav'ac' 'iść pospiesznie, szorować', šl'ain'un $\leq$ sllac:e 'szlajać się', šłap'un $\leq$ štapav'ac' 'iść, pozostawiając na powierzchni brudne ślady', šnyr'un $\leq$ šn'yryc' 'chodzić myszkując', tapt'un $\leq$ tapt'ac:e 'kręcić się pod nogami', tauk'un $\leq$ tauč'ys'e 'kręcić się pod nogami', trap'un

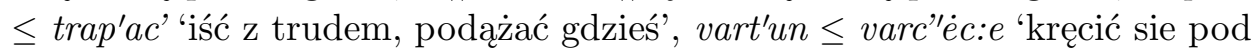
nogami'.

- $\mathbf{N}_{\text {SUB }}$ z FS - $a \check{c}(25)$ :

$b^{\prime} i y^{\prime} a c c^{\prime} \leq b^{\prime}$ 'é $a c$ ' 'być w ciągłym ruchu, spieszyć się', bryk'ač $\leq b r^{\prime} y k a c$ ' 'żywiołowo biegać podskakując, swawolić', c'ay'ač $\leq$ c'oyac:e 'włóczyć się, chodzić bez celu', dapt'ač $\leq$ dapt'ac:e 'kręcić się pod nogami', drynd'ač $\leq d r^{\prime} y n d a c$ ' 'iść ociężale, tracąc siły', dryp'ač $\leq d r^{\prime} y p a c$ ' 'iść ociężale, z trudem', dynd'ač $\leq d^{\prime} y n d a c$ ' 'chodzić niezgrabnie, powłóczac nogami', $3 y \gamma^{\prime} a \check{c}$ $\leq 3^{\prime}$ y $а a c$ ' 'skakać, iść podskakując', kauz'ač $\leq k^{\prime}$ 'ouzac:e 'ślizgać się, np. po lodzie, oblodzonym chodniku', klynd'ač $\leq k t^{\prime} y n d a c$ ' 'chodzić niezgrabnie, po- 
włócząc nogami', klyp'ač $\leq k t^{\prime} y p a c$ ' 'iść ociężale', krut'ač $\leq k r u c$ 'ic:e 'kręcić się, krążyć', kul' $\gamma^{\prime} a \check{c} \leq k u l^{\prime} \gamma^{\prime} a c$ ' 'iść kulejąc, utykając na nogę', patyk'ač $\leq p a-$ tyk'ac:e 'iść potykając się o coś', pauz'ač $\leq p^{\prime} o u z a c$ ' 'pełzać, iść na czworakach', spatyk'ač $\leq$ spatyk'ac:e 'iść potykająć się o coś', štap'ač $\leq \check{s} t^{\prime} e p a c$ ' 'człapać, štynd'ač $\leq \check{s} t^{\prime} y n d a c$ ' 'chodzić niezgrabnie', švend'ač $\leq \check{s} v^{\prime} e n d a c: e$ 'szwendać się, chodzić bez celu', tapt'ač $\leq$ tapt'ac:e 'plątać się w pobliżu', trap'ač (2)

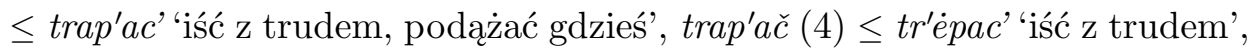
$u c^{\prime} i k^{\prime} a c ̌ \leq ~ u c^{\prime} i k^{\prime} a c^{\prime}$ 'uciekać (np. ze strachu)', zainivan"ač $\leq$ zainivan" $a c$ ' 'pędzić, zaiwaniać', zap'erdal'ač $\leq$ zap'erdal' $a c$ ' 'pędzić, mknąć'.

\section{- $\mathrm{N}_{\mathrm{SUB}}$ z FS -auka (14):}

br'ontauka $(1) \leq$ br'ontac:e 'plątać się pod nogami', br'ontauka $(2) \leq$ br'ontac:e 'włóczyć się', c"oуauka $\leq$ c"oyac:e 'włóczyć się', dr'ypauka $\leq d r$ 'ypac' 'bezustannie chodzić, być w ciągłym ruchu', d'yndauka $\leq$ d'yndac' 'chodzić

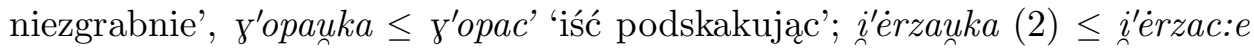
'kręcić się', kt'ypauka $\leq k t^{\prime} y p a c$ ' 'iść niezgrabnie', r'eidauka $\leq$ r'eindac:e 'iść, kiwając się na boki', pl'ontauka $\leq$ pl'ontac:e 'plątać się pod noga-

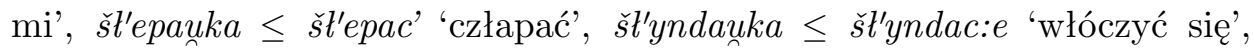
šv'endauka $\leq \check{s} v^{\prime} e n d a c: e$ 'włóczyć się', tr'épauka $\leq$ tr'épac' 'dreptać'.

- $\mathbf{N}_{\text {SUB }}$ z FS - ak (6):

čłap'ak $\leq$ čt'epac' 'człapać, wlec się', $\chi a d^{\prime} a k \leq \chi a z^{\prime \prime} i c$ ' 'bezustannie chodzić', praid'ak $\leq$ prais'c' $i$, por. praes. praid-'ut 'przejść', šłap'ak $(1) \leq s_{n} t^{\prime} e p a c$ ' 'czła-

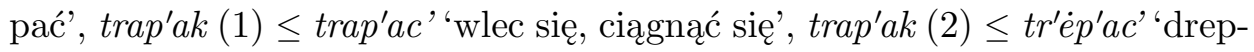
tać'.

\section{- $\mathbf{N}_{\text {SUB }}$ z FS - n'ik (5):}

bl'udn'ik $\leq$ bluz'ic' 'błądzić, mylić drogę, yul'al'nik $\leq$ yul'ac' 'włóczyć się, hulać', kal'adn'ik $\leq$ kal'adav'ac' 'włóczyć się po wsi, chodzić od domu do domu', prybt'udn'ik $\leq$ prybłuz'ic:e 'przybłąkać się', vandr'oun'ik $\leq$ vandrav'ac' 'wędrować, łazić'.

\section{$-\mathrm{N}_{\mathrm{SUB}}$ z FS $-i k(4)$ :}

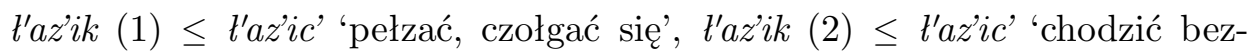
ustannie', $p^{\prime}$ ouz'ik $\leq$ p'ouzac' 'raczkować, pełzać', v'erc'ik $\leq$ varc'éc:e 'kręcić sie, być w ciągłym ruchu'.

\section{- $\mathbf{N}_{\text {SUB }}$ z FS -l'ec (3):}

pryb'yl'ec $\leq$ pryb'yc' 'przybyć', pryšél'ec $\leq$ pryisscc'i 'przyjść, przybyć', sk'it'al'ec $\leq$ sk'it'ac:e 'poniewierać się, tułać się'. 
- $\mathbf{N}_{\text {SUB }}$ z FS -aka (3):

$k u l \gamma^{\prime} a k a \leq k u l^{\prime} \gamma^{\prime} a c$ ' 'iść kulejąc', yul'aka $\leq$ zul'ac', 'chodzić bez celu, beztrosko spędzać czas', praind'aka $\leq$ prains'c'i, por. praes. praid-'ut 'przejść'.

- $\mathbf{N}_{\mathrm{SUB}}$ z FS - $\dot{e} \boldsymbol{l}^{\prime}(3)$ :

$k r u t^{\prime} a \check{c}-k r u c$ 'el' 'kręcić się pod nogami', taukk'èl' $\leq$ taučc'ys'e 'plątać się pod nogami', varc"él' $\leq$ varc'èc:e 'kręcić się pod nogami'.

- $\mathbf{N}_{\text {SUB }}$ z FS -ok (2):

$\chi a d^{\prime} o k \leq \chi a 3^{\prime \prime} i c$ ' 'chodzić (często)', iiizd'ok $\leq i_{n}^{\prime} \dot{e} z z^{\prime} i c$ ' 'jeździć (często)'.

- $\mathbf{N}_{\text {SUB }}$ z FS -ec (2):

vandr'ovec $\leq$ vandrav'ac' 'chodzić bez celu', zul'ec $(2) \leq$ zul'ac' 'chodzić bez celu, próżnować'.

- $\mathbf{N}_{\text {SUB }}$ z FS -n'ec (2):

k'ouzan'ec $\leq$ k'ouzac:e 'ślizgać sie, np. po oblodzonym chodniku, lodzie', šl'opan'ec $\leq \check{s} l^{\prime}$ 'opac' 'iść człapiąc nogami'.

- $\mathbf{N}_{\text {SUB }}$ z FS - da (2):

čyk'ełd'a $a$ čyk'el'ac' 'chodzić utykając, kuleć', šl'aida $\leq$ sll'ac:e 'włóczyć się'.

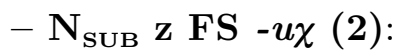

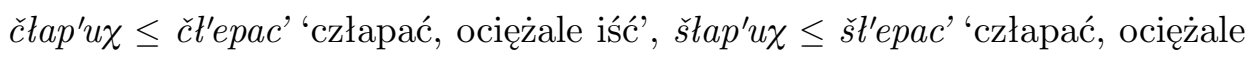
iść'.

- $\mathbf{N}_{\text {SUB }}$ z FS - иуa (2):

tatr'uуa $\leq$ t’otryc:e 'włóczyć się, błąkać się', vałač'uуa $\leq$ vałač'yc:e 'włóczyć się'.

- $\mathbf{N}_{\text {SUB }}$ z FS -al' (2):

$d y n d^{\prime} a l$ ' $\leq d^{\prime} y n d a c$ ' 'iść niezgrabnie, ociężale', ktynd'al' $\leq k t^{\prime} y n d a c$ ' 'niezgrabnie chodzić, powłócząc nogami'.

- $\mathbf{N}_{\mathrm{SUB}}$ z FS - $u \boldsymbol{l}^{\prime}(2)$ :

$\chi a d^{\prime} u l$ ' $\leq \chi a z^{\prime \prime} i c$ ' 'chodzić', tauk'ul' $\leq$ tauč 'ys'e 'kręcić się pod nogami'.

- $\mathbf{N}_{\text {SUB }}$ z FS -an (2):

ras'an $\leq$ ras'ac' 'beztrosko biegać, skakać', kaunz'an $\leq k^{\prime}$ ouzac:e 'ślizgać się, np. po oblodzonym chodniku, lodzie'.

- $\mathbf{N}_{\text {SUB }}$ z FS - ša (2):

$k t^{\prime} e p \check{s} a \leq k t^{\prime} e p a c$ ' 'człapać, niezgrabnie chodzić', $k t^{\prime} y p \check{s} a \leq k t^{\prime} y p a c$ ' 'człapać, niezgrabnie chodzić'. 
- $\mathbf{N}_{\text {SUB }}$ z FS - $\dot{o c}$ e (1):

trap'óc'e $\leq$ trap'ac' 'iść z trudem, człapać'.

$-\mathrm{N}_{\mathrm{SUB}} \mathrm{z}$ FS -inda (1):

št'ynda $\leq$ šl'ac:e 'włóczyć się'.

- $\mathrm{N}_{\mathrm{SUB}} \mathrm{z}$ FS -anz"a (1):

šlapanz" $a \leq$ šłapav'ac' 'iść, pozostawiając na powierzchni brudne ślady'.

- $\mathbf{N}_{\text {SUB }}$ z FS - enya (1):

Łaz'enya $\leq$ t'az'ic' 'łazić, włóczyć się'.

- $\mathbf{N}_{\text {SUB }}$ z FS $-a i$ (1):

vałač'ai $\leq$ vałačyc:e 'włóczyć się'.

- $\mathbf{N}_{\text {SUB }}$ z FS -l'n'ik (1):

yul'al'nik $\leq$ yul'ac' 'włóczyć się, hulać',

- $\mathbf{N}_{\text {SUB }}$ z FS -l'ščyk (1):

trap'al'ščyk $\leq$ trap'ac' 'iść, wlec się'.

- $\mathbf{N}_{\text {SUB }}$ z FS -sa (1):

br'yksa $\leq$ br'ykac' 'biegać podskakujacc'.

- $\mathbf{N}_{\text {SUB }}$ z FS - us' (1):

v'ertus' $\leq$ varc'èc:e 'być w ciągłym ruchu, kręcić się wokól'.

- $\mathbf{N}_{\text {SUB }}$ z FS -ita (1):

vałak'ita $\leq$ vałač'yc:e 'włóczyć się'.

\section{Synonimika konstrukcji słowotwórczych}

- szeregi synonimiczne typu a : b : c : d : e (2)

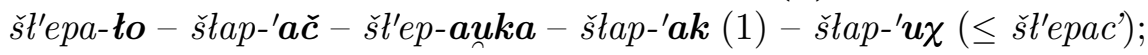

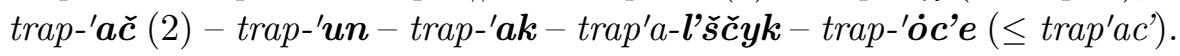

- szeregi synonimiczne typu a : b : c : d (13)

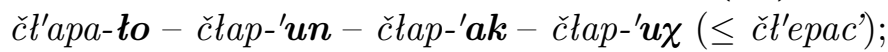
$d r^{\prime} y p a-\boldsymbol{t o}-d r y p-{ }^{\prime} \boldsymbol{u n}-d r y p-{ }^{\prime} \boldsymbol{a} \check{\boldsymbol{c}}-d r^{\prime} y p-\boldsymbol{a u k a}\left(\leq d r^{\prime} y p a c^{\prime}\right)$;

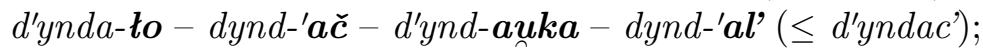

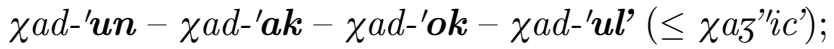
$k t^{\prime} y n d a-\boldsymbol{t o}-k t y n d_{-}{ }^{\prime} \boldsymbol{a} \check{\boldsymbol{c}}-k t y n d-' \boldsymbol{u n}-k t y n d_{-}{ }^{\prime} \boldsymbol{a l} '\left(\leq k t^{\prime} y n d a c^{\prime}\right)$; 
$k^{\prime} y p a-\boldsymbol{t o}-k t y p-{ }^{\prime} \boldsymbol{a} \check{\boldsymbol{c}}-k t^{\prime} y p-\boldsymbol{a u} \boldsymbol{k} \boldsymbol{a}-k t^{\prime} e p-\check{\boldsymbol{s}} \boldsymbol{a}\left(k t^{\prime} y p-\check{\boldsymbol{s}} \boldsymbol{a}\right)\left(\leq k t^{\prime} y p a c^{\prime}\right)$;

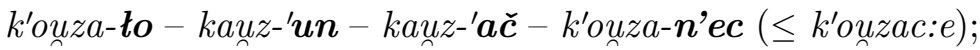

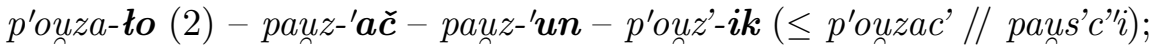

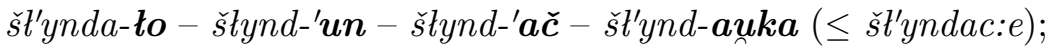

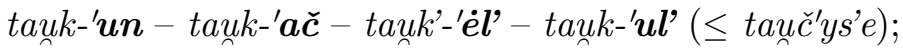

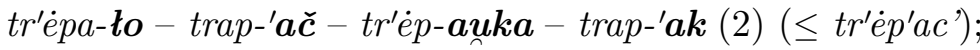

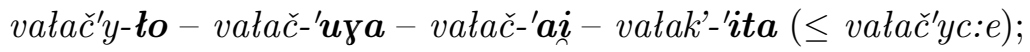

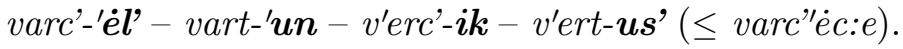

- szeregi synonimiczne typu a : b : c (9)

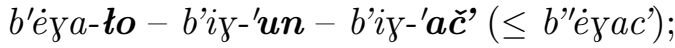

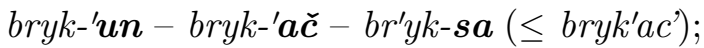

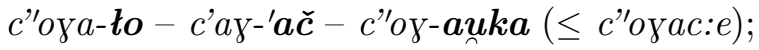

$k u l^{\prime} \gamma^{-}{ }^{\prime} \boldsymbol{a} \check{\boldsymbol{c}}-k u l^{\prime} \gamma^{-} \boldsymbol{u n}-k u l^{\prime} \gamma^{-}{ }^{\prime} \boldsymbol{a} \boldsymbol{k a}\left(\leq k u l^{\prime} \gamma^{\prime} a c^{\prime}\right)$;

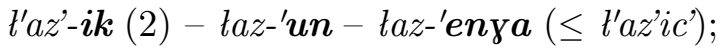

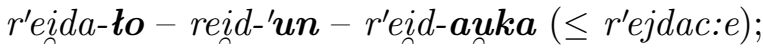

šl'ai-'un - šl' $a i-d a-\check{s} t-' y n d a\left(\leq s l^{\prime} a c: e\right)$;

šłap-'un - šs'ap-'ak - šs'ap-anz"a - ( $\leq$ šłapav'ac');

$\check{s} v^{\prime} e n d a-$ to $-\check{s} v e n d-{ }^{\prime} \boldsymbol{a} \check{c}-\check{s} v^{\prime} e n d-a u k \boldsymbol{a}$ ( $\left.\leq \check{s} v^{\prime} e n d a c: e\right)$;

- szeregi synonimiczne typu a : b (22)

br'onta-to (1) - bront-auka (1) ( $\leq$ br'ontac:e);

br'onta-to (2) - br'ont-auka (2) ( $\leq$ br'ontac:e);

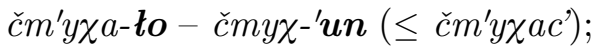

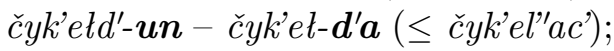

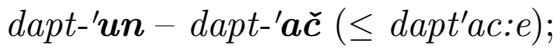

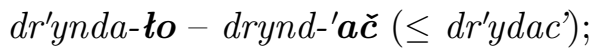

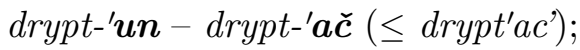

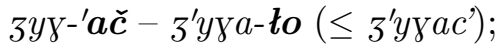

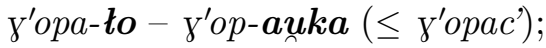

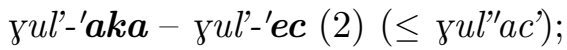

i'érza-to (2)-i i'érz-auka (2) ( $\leq$ i'érzac:e);

iizd-'un - iizd-'ok ( $\leq$ i' $\left.^{\prime} \dot{e} z^{\prime} \bar{\zeta}^{\prime} i c^{\prime}\right)$;

kal'ad-n'ik - kal'ad-'un ( $\leq$ kal'adav'ac');

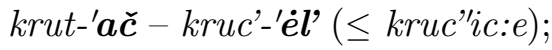

l'eta-to-l'it-un ( $\leq$ l'etac');

pl'onta-ło (3) - pl'ont-auka ( $\leq$ pl'ontac:e);

praid-'ak - praidd-'aka ( $\leq$ prains'c'i);

s'l'izga-to-s'lizg-'un ( $\left.\leq s^{\prime} l^{\prime} i z g a c: e\right)$;

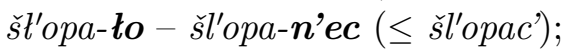




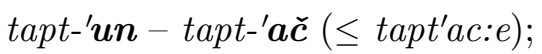

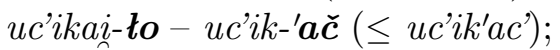

vandr'ơn-n'ik-vandr'ov-ec ( $\leq$ vandrav'ac');

- konstrukcje synonimiczne nietworzące szeregów synonimicznych (37):

$b t^{\prime} u d-\boldsymbol{n}^{\prime} \boldsymbol{i k}\left(\leq b\right.$ tuz $\left.^{\prime \prime} i c^{\prime}\right)$;

čar'apka-to ( $\left.\leq \check{c} a r^{\prime} a p k a c: e\right)$;

drat-'un ( $\leq$ dratav'ac');

$d^{\prime} y r d a-\boldsymbol{t o}\left(\leq d^{\prime} y r d a c^{\prime}\right)$;

$f^{\prime \prime} i k a-$ to $\left(\leq f^{\prime} i k a c^{\prime}\right)$;

$\chi l^{\prime \prime} u p a-$ to $\left(\leq \chi l^{\prime \prime} u p a c^{\prime}\right)$;

$\chi^{\prime} i t$ - $^{\prime}$ un ( $\left.\leq \chi^{\prime} i t^{\prime} a c: e\right)$;

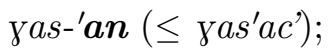

$\gamma^{\prime}$ opsa-to $\left(\leq \gamma^{\prime}\right.$ opsac' $)$;

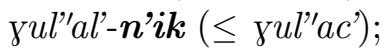

kar'apka-to ( $\leq$ kar'apkac:e);

kavyrk-'un ( $\leq$ kavyrk'ac:e);

kušt'yka-to ( $\leq$ kušt'ykac');

$\boldsymbol{\ell}^{\prime} a z^{\prime}-\boldsymbol{i k}(1)\left(\leq \boldsymbol{t}^{\prime} a z^{\prime} i c^{\prime}\right)$;

tatr-'uya ( $\leq$ t'otryc:e);

mašer-'un ( $\leq$ mašerav'ac');

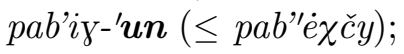

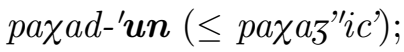

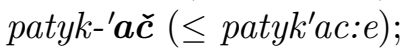

prybt'ud-n'ik ( $\leq$ prybtuz'ic:e);

pryb'y-l'ec ( $\leq$ pryb'yc');

račk-'un ( $\leq$ račkav'ac');

p'uta-to (2) ( $\leq p^{\prime}$ utac:e);

sat'yčy-to ( $\leq$ sat'yčyc:e);

sk'it'a-l'ec ( $\leq$ sk'it'ac:e);

sn'ova-to ( $\leq$ sna'vac:e);

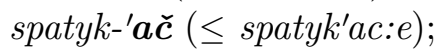

spacer-'un ( $\leq$ spacerav'ac');

šar-'un ( $\left.\leq \check{s} a r a v^{\prime} a c^{\prime}\right)$;

šnyr-'un ( $\left.\leq \check{s} n y^{\prime} r y c^{\prime}\right)$;

s'orya-to ( $\leq \check{s}^{\prime}$ oryac');

šp'ary-to (2) ( $\left.\leq \check{s} p^{\prime} a r y c '\right)$;

s'ura-to (1) ( $\left.\leq \check{s}^{\prime} u r a c^{\prime}\right)$;

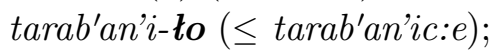




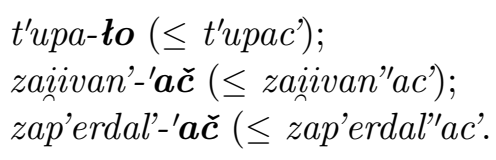

\section{Uwagi końcowe}

- Dewerbalne pejoratywne nazwy subiektów określające osoby ze względu na czynności związane z poruszaniem się, przemieszczaniem się w przestrzeni są tworzone w peryferyjnych gwarach białoruskich okolic Lewkowa Starego na Białostocczyźnie za pomocą 30 FS.

- Nacechowanie pejoratywne derywatów nie zawsze wynika z udziału FS w procesie derywacji. Bardzo często jest ono rezultatem przeniesienia wartości emocjonalnej z czasownika motywującego na wyraz motywowany.

- Odczasownikowe pejoratywne nomina subiecti są rezultatem kojarzenia pejoratywnych, melioratywnych i neutralnych FS z PS czasowników neutralnych bądź nacechowanych ujemnie.

- W trakcie przeprowadzonych badań dokładnej analizie poddano konteksty, w jakich derywaty pejoratywne zostały użyte, ponieważ mogą one zawierać $\mathrm{w}$ sobie niedookreślone negatywne wartości.

- Określane osoby mogą wywoływać w mówiącym m.in. takie typy emocji negatywnej, jak: agresja, gniew, ironia, lekceważenie, niechęć, nienawiść, niezadowolenie, obraza, oburzenie, pogarda, politowanie, rozczarowanie, wrogość, wstręt, zazdrość, złośliwość, zniecierpliwienie.

- Najwięcej pejoratywów zanotowanych w peryferyjnych gwarach białoruskich okolicach Lewkowa Starego pojawia się wśród derywatów nazywających osoby, które charakteryzują się takimi cechami, jak:

- chodzić z trudem;

- chodzić niezgrabnie;

- chodzić drobnym krokiem;

- chodzić chwiejnym krokiem, zataczać się;

- chodzić spiesząc się;

- chodzić powoli;

- chodzić kulejąc;

- iść, pozostawiając na powierzchni brudne ślady;

- iść powodując powstawanie określonych odgłosów;

- iść powłócząc nogami;

- iść człapiąc nogami;

- chodzić bez celu;

- pospiesznie sie oddalać, uciekać; 
- kręcić się pod nogami;

- pełzać, czołgać się;

- ślizgać się po śliskiej powierzchni;

- pełzać, czołgać się;

- wspinać się, wdrapywać się gdzieś.

- W potocznym rozumieniu inny człowiek jest dla mówiącego konkurentem, którego należy zdyskredytować, skrytykować go za jego wady i słabości. Człowiek potępia to, co uważa za naganne, odbiegające od przyjętych $\mathrm{w}$ danym środowisku norm. Antropocentryzm potocznej percepcji rzeczywistości powoduje, że mieszkańcy wsi zdecydowanie częściej okazują wobec niej dezaprobatę niż manifestują postawę aprobującą.

- W białoruskich gwarach peryferyjnych okolic Lewkowa Starego występują liczne szeregi synonimiczne badanych struktur słowotwórczych. Najbardziej rozbudowany 5-elementowy szereg synonimiczny tworza derywaty oparte na podstawach słowotwórczych šł'epac' 'człapać' i trap'ac'. Wyodrębniono 13 czteroelementowych szeregów synonimicznych bazujących na podstawach słowotwórczych čt'epac', dr'ypac', d'yndac', $\chi a z^{\prime \prime} i c$ ', kt'yndac', kt'ypac', k'ouzac:e, p'ouzac'//paus'c'i, št'yndac:e, tauč'ys'e, tr'épac', vałač'yc:e, varc'éc:e. Do licznych (9) należą także trzyelementowe szeregi synonimiczne oparte na podstawach słowotwórczych b'éyac', bryk'ac', c"oyac:e, kul'y'ac', l'az'ic', r'eindac:e, šl'ac:e, šłapav'ac', šv'endac:e. Odnotowano ponadto 22 dwuelementowe szeregi synonimiczne, por. np. podstawy słowo-

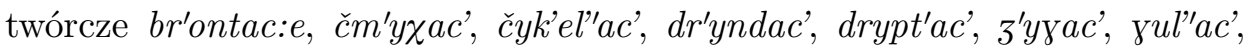
kruc'ic:e, l'etac', tapt'ac:e. Spośród badanych pejoratywów szeregów synonimicznych nie tworzac 24 derywaty, oparte m.in. na takich podstawach, jak błuz'ic', čar'apkac:e, drałav'ac', d'yrdac', kušt'ykac', p'utac:e, sat'yčyc:e, sk'it'ac:e, šarav'ac', šoryac', šp'aryc', s'urac'. W tej grupie w funkcji podstaw słowotwórczych występują liczne czasowniki zapożyczone w ostatnim okresie z języka polskiego i innych języków słowiańskich.

Dublety strukturalne występują pomiędzy formantami sufiksalnymi o identycznej lub zbliżonej dystrybucji, rywalizującymi o prymat w systemie słowotwórczym gwary, por. formanty słowotwórcze -ło, -ač, -un, -auka. Jest to zjawisko szczególnie charakterystyczne dla gwar o charakterze peryferyjnym, do jakich należą badane gwary białoruskie okolic Lewkowa Starego. W szeregach synonimicznych pojawiają się również formacje rzadziej notowane, w tym archaiczne, jak również zapożyczone języka ogólnopolskiego.

- Spośród omówionych typów słowotwórczych dewerbalnych pejoratywnych nazw subiektów najwyższą liczebnością charakteryzują się typy z formantem -ło (41), -un (33), -ač (25) oraz - auka (14). Mniejszą liczebność 
mają typy słowotwórcze z formantami -ak (6), -n'ik (5), -ik (4), a pozostałe charakteryzują się znikomą liczebnością, por. -l'ec (3), -aka (3), -èl' (3),

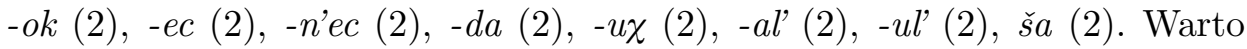
również odnotować wyodrębnienie 9 formacji z jednostkowym formantem słowotwórczym: -inda (1), -anz'a (1), -епуa (1), -uуa (1), -ai (1), -l'n'ik (1), -l’ščyk (1), -sa (1), -ita (1).

\section{I T E R A T U R A}

Dokulil M., Tvoření slov v češtině, 1. Teorie odvozování slov, Praha 1962.

Gołdowski K., Ekspresywizmy osobowe jako relewantne sktadniki kompetencji jezykowo-kulturowej mieszkańców gminy Iwanowice w pow. krakowskim, Kraków 2015, [online], http://www.academia.edu/19519069 [dostęp: 30.05.2017].

Grabias S., O ekspresywności języka. Ekspresja a stowotwórstwo, Lublin 1980.

Grzesiuk A., Sktadnia wypowiedzi emocjonalnych, Lublin 1995.

Kowalska A., Z badań nad mazowiecka leksyka ekspresywna (nazwy 'człowieka z wytrzeszczonymi oczami'), „Zeszyty Naukowe Uniwersytetu Gdańskiego. Prace Językoznawcze" 1993, nr 17-18.

Kulturowo-językowe dziedzctwo Podlasia, t. 1. Opis socjolingwistyczny regionu na tle uwarunkowań historycznych, red. N. Barszczewska, M. Chaustowicz, M. Timoszuk, Warszawa 2016.

Kurdyła T., Funkcje formantów rzeczownikowych w polszczyźnie ludowej (na przykładzie trzech wsi podkarpackich), Kraków 2011.

Lubaś W., Polskie gadanie. Podstawowe cechy i funkcje potocznej odmiany polszczyzny, Opole 2003.

Malec T., Budowa rzeczowników i przymiotników w gwarze wsi Rachanie pod Tomaszowem Lubelskim, Wrocław 1976.

Marciniak-Firadza R., Nazwy osobowych wykonawców czynności w gwarach matopolsko-mazowieckiego pogranicza językowego, cz. I. Studium stowotwórczo-leksykalne, Łódź 2013.

Michaluk D., Dobra i miasteczko Narewka na tle dziejów regionu (do końca XIX w.), Białystok - Narewka 1997.

Marciniak-Firadza R., Dukawka, gulgot, sepiot..., czyli jak w gwarach małopolsko-mazowieckiego pogranicza jezzykowego nazywa sie człowieka, który sie jąka, betkocze czy sepleni, „Rozprawy Komisji Językowej ŁTN” 2017, LXIV.

Matusiak-Kempa J., Dobre i zte w ludzkiej mowie - o wartościowaniu utrwalonym w dawnych przezwiskach, „Poznańskie Studia Polonistyczne. Seria Językoznawcza" 2017, vol. 24 (44), nr 1. 
Rejter A., Leksyka ekspresywna w historii języka polskiego. Kulturowo-komunikacyjne konteksty potoczności, Katowice 2006.

Sajewicz M., Derywacja sufiksalna osobowych nazw subiektów w nadnarwiańskich gwarach białoruskich Białostocczyzny. Deverbativa, deadiectiva, Lublin 2002.

Sajewicz M., Dublety strukturalne w kategorii dewerbalnych nomina agentis w gwarach z pogranicza białorusko-ukraińskiego na Białostocczyźnie, „Rozprawy Slawistyczne" 1989, nr 4.

Sajewicz M., O białorusko-ukraińskiej granicy językowej na Białostocczyźnie, „Rozprawy Slawistyczne" 1997, nr 12.

Scâcko P., Belaruskae narodnae slovautvarènne. Afiksal'nyâ nazoǔniki, Mìnsk 1977 [Сцяцко П., Беларускае народнае словаутварэнне. Афіксальнья назоўнікі, Мінск 1977].

Wiśniewski J., Zarys dziejów osadnictwa na Białostocczyźnie, [w:] Atlas gwar wschodniosłowiańskich Białostocczyzny, t. 1, red. Glinka, A. Obrębska-Jabłońska, J. Siatkowski, Zakład Narodowy im. Ossolińskich, Wydawnictwo PAN Wrocław -Warszawa - Kraków - Gdańsk 1980.

Vinokur G., Zametki po russkomu slovoobrazovaniû, [v:] Izbrannye raboty po russkomu âzyku, Moskva 1959 [Винокур Г., Заметки по русскому словообразованию, [в:] Избранные работы по русскому языку, Москва 1959].

\section{S U M M A R Y}

\section{PEJORATIVE NAMES OF SUBJECTS DENOTING A PERSON WITH REGARD TO MAKING MOVEMENT, MOTION IN SPACE IN THE PERIPHERAL BELARUSIAN DIALECTS OF LEWKOWO STARE IN THE BIALYSTOK REGION}

Pejorative deverbal names of subjects with a suffixal formant denoting a person with regard to making movement, motion in space are discussed in the article. The names are used in the peripheral Belarusian dialects of Lewkowo Stare. They refer mainly to men who perform an action. They can also be ambivalent with regard to grammatical gender. In the study about 170 derivatives formed by means of 30 suffixal formants have been analyzed. The analysis of the collected material has enabled to distinguish not only appropriate word-formation types within the studied category of names but also many and highly extended synonymic sequences of the analyzed derivational structures.

Key words: Bialystok region, peripheral Belarusian dialects, word formation, names of subjects, personal pejoratives, word-formation types, synonymic sequences. 